\title{
Eugenía e selecção
}

Pelo dr. José de Almeida Camargo.

$\mathbf{O}$

Sr. Paulo de Godoy, que desassombradamente se colloca na vanguarda do espirito e da cultura do seu tempo, offerece-nos, com sua theése de doutoramento-Eugenia e selecção-, a opportunidadè para algumas reflexões.

Mais um exemplo de que se pode ser scientista e ter os olhos acordados para regiões menos positivas; de que se pode ser estudioso sem se exprimir em linguagem de laboratorio; de que se pode ser medico sem fazer literatura gramatical.

Porque - com as excepções da chapa - , as letras medicas que por ahi campeiam:

ou se fazem á custa do Sr. Laudelino Freire-literatura meúda de crase e malabarismos pronominaes (o prejuizo que nos trouxe o exemplo de Francisco de Castro e o prejuizo que nos traz a furia literaria sempre crescente do Sr. Austregesilo!);

"Violon de Ingres"

ou se fazem á custa das visceras alheias.

Com effeito, ha homens que acreditam que fazem literatura estudando as doenças dos seus clientes; ou contando anecdotas medicas, quasi sempre fesceninas; ou estudando o prognasismo dos Habsbourgos.

"Les gens de lettres" (o Sr. Maurice de Fleury é um grande talento) devem seguir o seguinte regimem;

levantar-se ás.

almoçar ás.

Era o regimen seguido por Mr. Zola e Mr. Hugo.

Traducção franceza, mais humoristica que o texto inglez, de Mark Twain:

“Quand j'étais' enfant, j'ai dû fabriquer du savon, bien que mon pére fû riche; j'ai dû me lever de bonne heure le matin, et étudier la géométrie á déjeuner, et m’en aller vendre des vers que j'avais composés, et agir en tout exactament comme feu Benjamin Franklin, dans le bel espoir que je serais un jour un Franklin. 
Et voyez ce je suis devenu!"

E' mais honesto fazer como o Sr. Charles Baudouin, pesquizando o determinismo psychologico da poesia de Verhaeren, conforme Freud, que andar com o Dr. Pierre Mauriac a vasculhar as crises asthmaticas de Marcel Proust.

Isto não são artes, nem sciencias nem letras.

No maximo é missa de corpo presente.

O Sr. Paulo de Godoy, de começo, com a agilidade e o enthusiasmo que caracterizam a sua penna, faz a "mise au point" do espirito moderno brasileiro.

O homem americano, que pasmou ante á violencia da terra bruta, faz de seu proprio espanto uma razão de victoria.

Ingenuo e confiante, da ingenuidade mesma fabrica a clava de sua força constructora.

Tudo lhe é novo sob o sol.

E o espectaculo primeiro, despe-o da cultura exhausta e cansada de outros povos, atirando á sàlsugem dos portos a veste ficticia de todos os "ismos" imaginados.

"E o brado se espraia por todas as praias:

I AM! YO SOY! EU SOU!”

Da necessidade de uma missão a cumprir, o autor de "Eugenia e selecção" passa a encarar a nossa ethnica, abordando a questão da eugenia.

Não quero transladar para aqui as considerações expostas tão brilhantemente pelo autor para a affirmação de sua thése-deixancio-as assim para o paladar immediato do leitor.

Quero apenas fazer notar que o Sr. Paulo de Godoy acaba justamente de effectuar um acto nobilissimo: - apeiou-se da idealogia secular para desccer á vida, que é o seu caminho.

Um erro fundamental: - estabelecimento de dogmas, leis, regras, - padrão emfim, - obrigando a vida a segui-los. Quando deveriam cingir-se á vida, que é a sua razão de ser.

Erro e motivo de dôr.

Erro-antibiologico.

Motivo de dôr-perdemos o roteiro da vida e depois andamos a procurál-o, como doidos, no emaranhado das ficções!

E' por isso que o autor de "Eugenia e Seleção" é actual, biologico e, portanto, verdadeiro, quando aborda o problema da eugenia 
e preconiza a esterelização dos que só podem dar descendencia inutil e prejudicial. outro.

E' um ponto de vista mais largo e mais humano que qualquer

De quem se levanta acima do egoismo individual para espraiar a vista na visão panoramica da especie.

- "Eugenia e selecção" —. E' verdade que o Sr. Paulo de Godoy é immoral?

Ha uma admiravel legenda para caricaturas de Alvaro Moreyra, mais ou menos assim:

- E' verdade que o poeta Verlaine bebia muito?

- Você já leu os versos de Verlaine?

- Ainda não.

- Então, para que quer saber? 